\title{
ZNF687 wt Allele
}

National Cancer Institute

\section{Source}

National Cancer Institute. ZNF687 wt Allele. NCI Thesaurus. Code C98009.

Human ZNF687 wild-type allele is located in the vicinity of $1 \mathrm{q} 21.2$ and is approximately 10 $\mathrm{kb}$ in length. This allele, which encodes zinc finger protein 687 , is involved in transcriptional regulation. A translocation involving this gene and the RUNX1 gene may be associated with acute myeloid leukemia. 